\title{
Abdominal Aorta Hypoplasia: A Rare Aortic Anomaly
}

\author{
๑ Tülay Demircan1, ๑ Onur Işsı², ๑ Barış Güven1, ๑ Muhammet Akyüz²
}

1University of Health Sciences, İzmir Tepecik Training and Research Hospital, Clinic of Pediatric Cardiology, İzmir, Turkey

2University of Health Sciences, İzmir Tepecik Training and Research Hospital, Clinic of Pediatric Cardiovasculary Surgery, İzmir, Turkey

\section{Dear Editor,}

Abdominal aortic hypoplasia is very rare anomaly seen in the literature ${ }^{(1,2)}$. There are only few case presentations for this diagnosis. Etiological reasons are less known. But these include developmental defects, infectious, inflammatory causes and genetic syndromes such as neurofibromatosis, Williams Bauren syndrome and hypomelanosis Ito $^{(3,4)}$. In this article we present rare cases images of abdominal aortic hypoplasia. A 3-year-old girl was referred to our clinic with hypertension. Previous history was insignificant. The patient complained post-prandial pain and extremity pain. On physical examination, body weight and height were $10 \mathrm{~kg}(<3$ percentile), $75 \mathrm{~cm}(<3$ percentile), respectively. There were no skin manifestations or dismorphic signs or mental retardation. Pulse rate was 110/min; blood pressure was measured from the right lower extremity $85 / 51 \mathrm{mmHg}$, from the right upper extremity 110/68 mmHg. Her general condition was good. Chest X-ray and electrocardiogram were normal. Blood tests were normal including renal function parametars. These findings make think that the patient might have the aortic coarctation. Echocardiography was assessed as normal. Thoracic computed tomography angiography was revealed doubtful image of stenosis of T12 segment at descending aorta (Figure 1). Catheter angiography was performed. The catheter was inserted into the aorta via the femoral artery and an opaque material injection was performed. All of the segments of the abdominal aorta starting from the mid-thoracic aortic level appeared to be the hypoplastic. A multiple colleteral vessels were observed (Figure 2). A large Riolan arcade was noted. Both iliac arteries were mildly hypoplastic. The procedure was terminated immediately to ensure that the circulation of the nourished region was not impaired. Nevertheless a color change was observed starting from the inguinal till to the umbilical region. About an hour later, the color change was disappeared. All with these findings, the patient was diagnosed with abdominal aortic hypoplasia. Because of asymtomatic nature of diagnosis, the patient scheduled for clinical follow-up and started the antihypertensive medication as nifedipin. However, if renal insuffiency, mesenteric ischemia, medically uncontrolled hypertension, and leg claudication were present, it was

Address for Correspondence: Tülay Demircan, University of Health Sciences, İzmir Tepecik Training and Research Hospital, Clinic of Pediatric Cardiology, İzmir, Turkey

Phone: +90 5057538760 e-mail: tulay.sirin@hotmail.com ORCID ID: orcid.org/0000-0002-2529-2906

Received: 17.10.2018 Accepted: 19.12.2018

Cite this article as: Demircan T, Güven B, Işık O, Akyüz M. Abdominal Aorta Hypoplasia: A Rare Aortic Anomaly. EJCM 2019;7(1):47-48.

DOI: $10.32596 / \mathrm{ejcm}$. galenos.2018.00051

${ }^{\circ}$ Copyright 2019 by Heart and Health Foundation of Turkey (TÜSAV) / E Journal of Cardiovascular Medicine published by Galenos Publishing House. 


Letter to the Editor 48
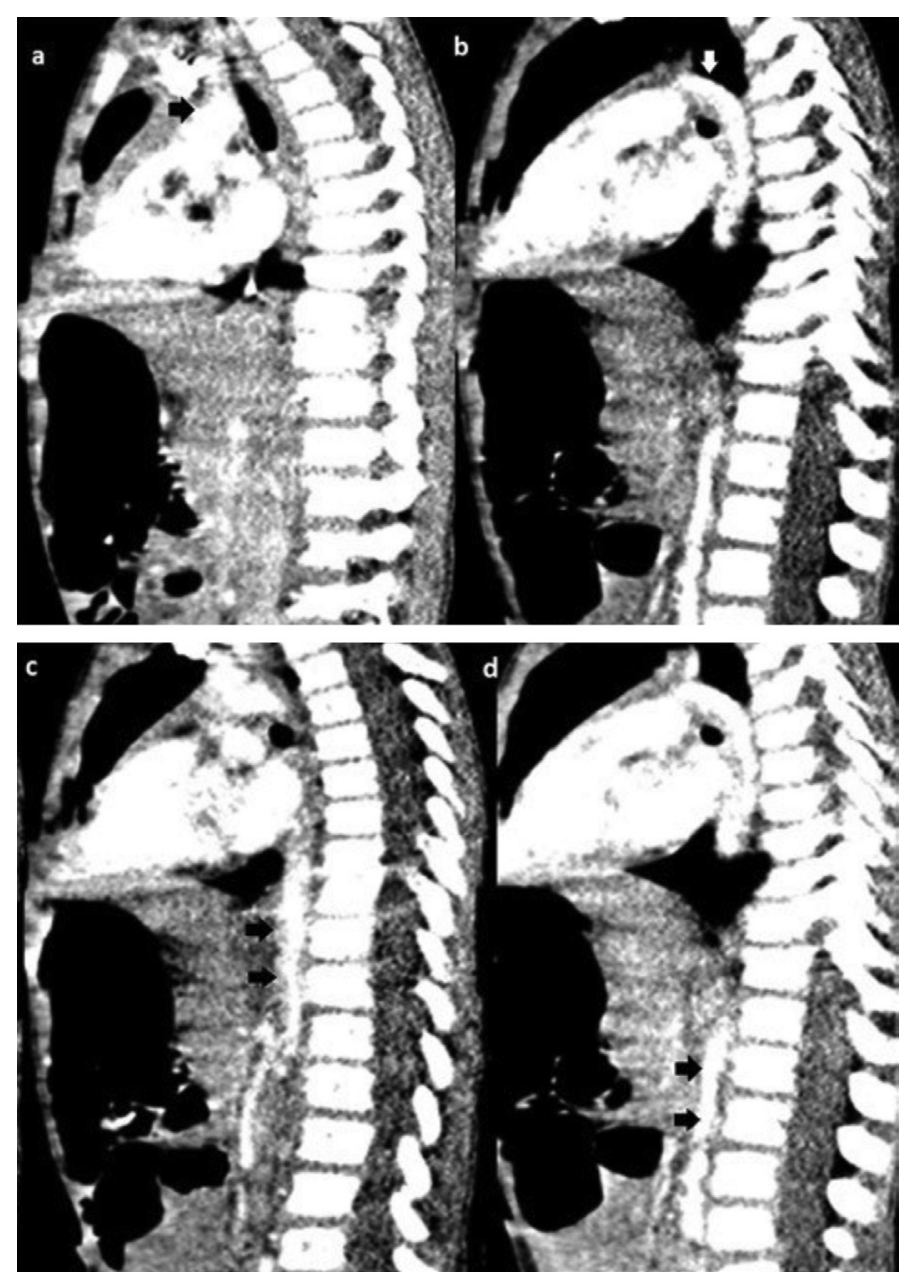

Figure 1. Computed tomography angiography in case showing diffuse narrowing of the descending thoracic and abdominal aorta (arrows)

informed that surgery could be recommended to relieve the patient's symptoms.

\section{Ethics}

Peer-review: Externally peer-reviewed.

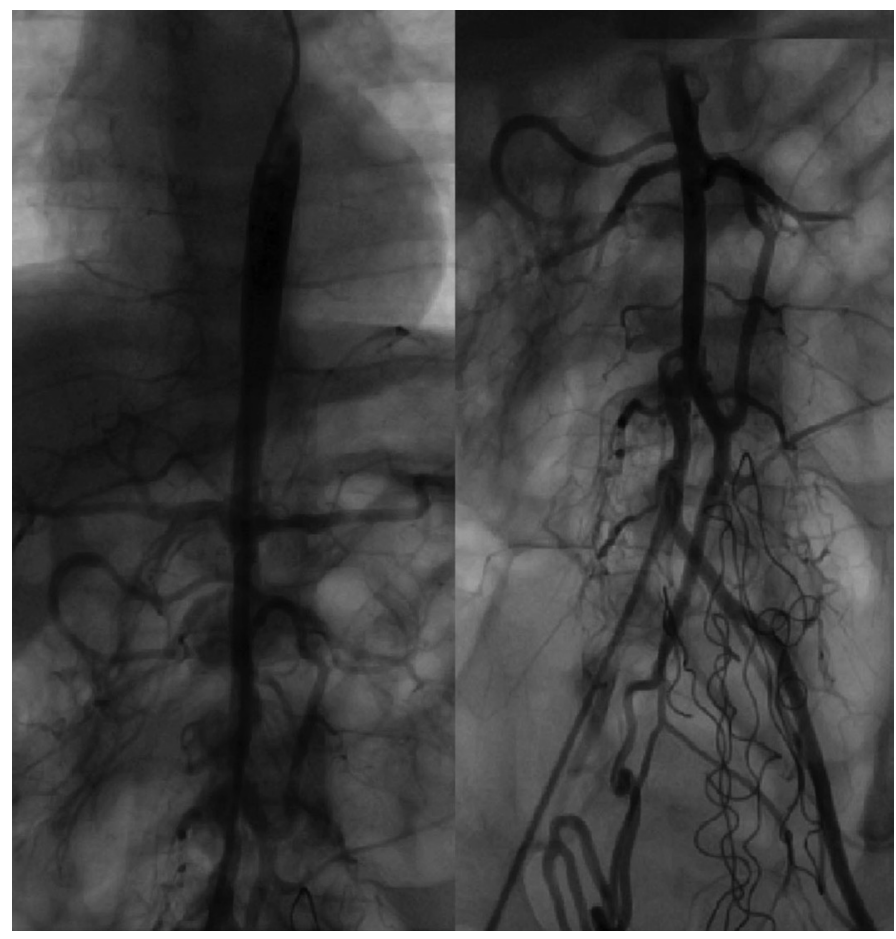

Figure 2. All segment of the abdominal aorta from the midthoracic aortic level appeared to be the hypoplastic. A multiple colleteral vessels were observed

\section{References}

1. Coutance G, Labombarda F, Cauderlier E, Richard P, Bonne G, Chapon F. Hypoplasia of the aorta in a patient diagnosed with LMNA gene mutation. Congenit Heart Dis 2013;8:127-9.

2. Grebeldinger SP, Balj SS, Adic O. Severe diffuse hypoplasia of the aorta associated with multiple vascular abnormalities. Vascular 2011;19:170-4.

3. Terramani TT, Salim A, Hood DB, Rowe VL, Weaver FA. Hypoplasia of the descending thoracic and abdominal aorta: a report of two cases and review of the literature. J Vasc Surg 2002;36:844-8.

4. Paşaoglu L, Toprak U, Akdal B, Acar D, Koparal S. Abdominal Aortic Hypoplasia, a Rare Cause of Hypertension. British Journal of Medicine \& Medical Research 2015-7:789-94. 